\title{
ANALISIS HUBUNGAN FUNGSIONAL JUMLAH MASYARAKAT MUSLIM DAN PEMBANGUNAN MASJID/MUSHOLAH DI SULAWESI SELATAN
}

\author{
Mifda Hilmiyah, Khaerun Nisa, Jeni Ayu \\ Institut Agama Islam Negeri (IAIN) Parepare \\ Email:mifdahilmiyah@stainparepare.ac.id,khaerunnisa@stainparepare.ac.id, \\ Jeniayulastri@stainparepare.ac.id
}

\begin{abstract}
Today the Muslim community is vying to establish a mosque / musholah. Because now the mosque / musholah not only used as a place of worship for Muslims. But also as a place of deliberation, a place to improve the intelligence and knowledge of the Muslims and the development and development of cadres of the leaders of the ummah.The type of this research is quantitativeand research method are correlation and regression analysis. Correlation analysis is used to test the significance and the relation between variables of Muslim population and mosque building. Meanwhile, regression analysis aims to determine the significance of the influence of Muslim population on building mosques in South Sulawesi Province. The results of this research indicate that the functional relationship between the number of Muslim population and the number of mosque buildings in South Sulawesi Province in 2015 is a positive linear pattern, the higher the Muslim population the higher the number of mosque buildings. Based on the results of correlation analysis obtained correlation coefficient between variables is strong that is 0.894 and significantly correlated. Meanwhile, based on regression analysis, it is found that there is significant influence between population and mosque building in South Sulawesi Province in 2015.
\end{abstract}

Keywords: Moslem, Mosque Building, Correlation Analysis, Regression Analysis

\section{PENDAHULUAN}

Masyarakat muslim adalah masyarakat yang istimewa, tidak seperti masyarakat-masyarakat yang dikenal oleh manusia sepanjang sejarah, Hal ini karena masyarakat muslim adalah masyarakat yang dibentuk oleh syari'at Islam yang kekal, yang diturunkan oleh Allah dengan sempurna sejak hari pertama. ${ }^{1}$ Islam sebagai agama universal (kaffah atau menyeluruh) ditakdirkan sesuai dengan tuntunan tempat dan zaman. Di dalam Islam tersedia prinsip-prinsip dasar

\footnotetext{
${ }^{1}$ Muh, Al-hasyimi ali, 2009. Hakikat masyrakat muslim. Indonesia: Islam House
} 
kesempurnaan itu, prinsip yang tidak akan mengalami perubahan sedikit pun sepanjang sejarah umat manusia.

Tempat beribadah umat Islam disebut masjid, tidak disebut marka (tempat ruku') atau kata lain semisal dengannya yang menjadi rukun shalat. Kata masjid disebut duapuluh delapan kali di dalam al-Quran.Secara harfiah, masjid berasal dari Bahasa Arab yaitu sajada, yasjudu, sujudan.Dalam Kamus al-Munawwir (1997: 610), berarti membungkuk dengan khidmat. Dari akar kata tersebut, terbentuklah kata masjid yang merupakan kata benda yang menunjukkan arti tempat sujud (isim makan dari fi'il sajada). Sujud adalah rukun shalat, sebagai bentuk ikhtiar hamba dalam mendekatkan diri pada Allah SWT.Sujud juga dapat diartikan sebagai perbuatan meletakkan kening ke tanah, secara maknawi mengandung arti menyembah.Sedangkan sajadah berasal dari kata sajjadatun yang mengandung arti tempat yang dipergunakan untuk sujud, mengkerucut maknanya menjadi selembar kain atau karpet yang dibuat khusus untuk shalat orang per orang. Karena itu, karpet masjid yang lebar, meski fungsinya sama tetapi tidak disebut sajadah. ${ }^{2}$

Sejarah masjid bermula sesaat setelah Rasulullah Saw, hijrah di Madinah. Saat Rasulullah Saw tiba di Quba, pada hari Senin tanggal 8 Rabi'ul Awwal tahun ke-14 nubuwwah atau tahun pertama hijrah, bertepatan tanggal 23 September 662 M, beliau membangun masjid yang pertama yang disebut masjid Quba. Lokasinya berada di sebelah tenggara Kota Madinah. Jaraknya lima kilometer di luar Kota Madinah. Dijelaskan dalam sejarah, tokoh Islam yang memegang peranan penting dalam pembangunan masjid ini adalah sahabat Rasulullah yaitu 'Ammar ra.Saat Rasulullah Saw hijrah dari Makkah ke Madinah, pria ini mengusulkan untuk membangun tempat berteduh bagi Rasulullah di kampung Quba yang tadinya hanya terdiri atas hamparan kebun kurma.Kemudian, dikumpulkannya batu-batu dan disusun menjadi masjid yang sangat sederhana.Setelah masjid Quba, bangunan masjid yang selanjutnya dibangun oleh Rasulullah Saw adalah masjid

\footnotetext{
${ }^{2}$ Kurniawan, Syamsul. Jurnal Volume 4 no 2 September 2014 h. 170
} 
Mifdah Hilmiyah, Analisis Hubungan Fungsional...

Nabawi di Madinah. Rasulullah Saw, membangun Masjid Nabawi pada bulan Rabiul Awal di awal-awal hijrahnya ke Madinah. ${ }^{3}$

Masjid merupakan sarana untuk pemahaman serta pendalaman berbagai aspek keislaman tersebut. Dewasa ini umat Islam terus-menerus mengupayakan pembangunan masjid. Bermunculan masjid-masjid baru di berbagai tempat, di samping renovasi atas masjid-masjid lama. ${ }^{4}$ Masjid juga sebagai tempat beribadah bagi umat muslim,Fungsi utama masjid adalah tempat sujud kepada Allah SWT, tempat shalat, dan tempat beribadah kepada-Nya. Selain itu, masjid tempat kaum muslimin beri'tikaf, membersihkan diri dan mendapatkan pengalaman keagamaan. Masjid juga sebagai tempat bermusyawarah kaum muslimin guna menyelesaikan persoalan yang timbul dalam masyarakat. Masjid merupakan wahana untuk meningkatkan kecerdasan dan ilmu pengetahuan kaum muslimin serta pembinaan dan pengembangan kader-kader pemimpin umat. ${ }^{5}$ Hal ini dijelaskan dalam arti Surah At Taubah ayat 18:

Yang memakmurkan masjid-masjid Allah hanyalah orang-orang yang beriman kepada Allah dan Hari Kemudian, serta tetap mendirikan shalat, mengeluarkan zakat, dan tidak takut kepada siapa pun, kecuali kepada Allah, merekalah yang diharapkan termasuk golongan orang-orang yang mendapat petunjuk (QS At Taubah(9:18)

Selain itu, dijelaskan dalam hadist yang diriwayatkan oleh Ibn Majah dan Ibnu Hibban:

"Barang siapa membangun masjid karena mengharapkan ridha Allah SWT, yang di dalamnya tersebut (diingat) nama Allah, Allah membangn rumah untuknya di surga." (HR Ibn Majah dan Ibn Hibban)

Kehadiran masjid di tengah-tengah masyarakat, idealnya dijadikan pusat kegiatan masyarakat untuk berusaha mewujudkan tatanan sosial yang naik. Bagi masyarakat yang biasa memakmurkanya, masjid merupakan cermin sosialisasi nilai-nilai kehidupan yang dibangun di atas dasar keimanan dan ketakwaan. Sebab, secara teologis, masyarakatt Muslim meyakini sebagai tempat berkomunikasi antara hamba dan Khaliknya, tempat mengadu secara

\footnotetext{
${ }^{3}$ Ibid,.

${ }^{4}$ Ayub, Moh dkk. Manajemen Masjid 1996. Jakarta. Gema Insani.h.13

${ }^{5}$ Farid, Miftah. Lentera Ukhuwah. 2014. Bandung. Penerbit Mizan. h.68
} 
transendental, dan tempat menemukan makna kemanusiaan melalui interaksi dengan sesama jamaahnya.

Dalam konteks memakmurkan masjid, secara umum masjid perlu difungsikan sebagai: pertama, tempat pembinaan dan kaderisasi jamaah; dan kedua, tempat pembinaan dan kaderisasi pengurus (ta'mir)-nya.

Secara sederhana, jamaah masjid diartikan sebagai sekelompok orang yang menjadikan masjid sebagai ikatan jam ‘iyyah-nya.Kata lainnya adalah kumpulan anggota dari suatu masjid. Pada dasarnya jamaah masjid bisa kita bagi menjadi dua kategori, yaitu: jamaah tetap dan jamaah tidak tetap (musiman). Pembinaan jamaah masjid yang bisa dilakukan dalam hal ini Pembinaan ketauhidan (aqidah).Tauhid secara bahasa diambil kata wahhada yuwahhidu tauhidan yang artinya mengesakan.Satu suku kata dengan kata wahid yang berarti satu atau kata ahad yang berarti esa. Dalam ajaran Islam tauhid itu berarti keyakinan akan keesaan Allah SWT. Tauhid merupakan inti dan dasar dari seluruh tata nilai dan norma Islam, sehingga oleh karenanya Islam dikenal sebagai agama tauhid yaitu agama yang mengesakan tuhan. Secara istilah, tauhid berarti mengesakan Allah SWT dalam hal Mencipta, Menguasai, Mengatur dan mengikhlaskan (memurnikan) peribadatan hanya kepada-Nya, meninggalkan penyembahan kepada selain-Nya serta menetapkan Asma'ul Husna (Nama-nama yang Bagus) dan Shifat Al-Ulya (sifat-sifat yang Tinggi) bagi-Nya dan mensucikan-Nya dari kekurangan dan cacat.Tauhid sendiri adalah merupakan risalah atau ajaran yang dibawa oleh nabi Muhammad Saw, dan juga para nabi dan Rasul sebelum nabi Muhammad Saw, diutus oleh Allah. Hal ini ditegaskan oleh firman Allah SWT dalam QS al-Anbiya' (21): 25:

"Dan Kami tidak mengutus seorang rasulpun sebelum kamu, melainkan Kami wahyukan kepadanya: "Bahwasanya tidak ada tuhan (yang hak) melainkan Aku, maka sembahlah olehmu sekalian akan $A k u$ ".

Selain itu, pembinaan baca-tulis Al-Quran ini bisa dilakukan dengan kegiatan-kegiatan seperti kursus bacatulis Al Qur'an, dan semacamnya. Tentu saja orang-orang yang memberikan pembinaan baca tulis Al-Quran adalah orangorang yang berpengalaman di bidangnya, sehingga para jama'ah masjid betul- 
betul bisa merasakan manfaatnya.Dengan adanya pembinaan baca tulis Al-Qur'an ini, diharapkan para jama'ah masjid mengakrabi Al-Quran, membiasakan diri mengisi waktu luang dengan membaca Al-Quran, dan juga terusmenerus termotivasi untuk menggali dan mengkaji isi kandungan Al-Quran.

Pembangunan rumah ibadah, termasuk masjid telah diatur oleh pemerintah pada dalam Peraturan Bersama Menteri Agama dan Menteri Dalam Negeri No.9 Tahun 2006 dan No.8 Tahun 2006 tentang Pedoman Pelaksanaan Tugas Kepala Daerah/ Wakil Kepala Daerah Dalam Pemeliharaan Krukunan Umat Beragama, Pemberdayaan Forum Kerukunan Umat Beragama dan Pendirian Rumah Ibadah. Pendirian rumah ibadah dilaksanakan jika telah memenuhi syarat administratif dan syarat teknis. Hal ini diatur pada pasal 14 ayat (1) dan $(2)^{6}$ :

1. Daftar nama dan Kartu Tanda Penduduk pengguna rumah ibadah paling sedikit 90 orang yang disahkan oleh pejabat setempat sesuai dengan tingkat batas wilayah;

2. Dukungan masyarakat setempat paling sedikit 60 orang yang disahkan oleh lurah/kepala desa;

3. Rekomendasi tertulis kepala kantor departemen agama kabupaten/kota; dan

4. Rekomendasi tertulis Forum Kerukunan Umat Beragama kabupaten/kota.

Dengan adanya aturan tersebut, wilayah dengan mayoritas penduduk muslim dapat didirikan masjid sesuai dengan jumlah muslim di daerah tersebut.Provinsi Sulawesi Selatan merupakan wilayah yang sebagian besar masyarakatnya beragama Islam, pada tahun 2015 telah tercatat 7.416.488 jiwa masyarakat muslim yang ada di beberapa daerah Provinsi Sulawesi Selatan, dan telah tercatat 4663 tempat ibadah masyarakat muslim seperti masjid maupun musholah.

Tujuan dari penelitian ini adalah untuk mengetahui hubungan fungsional dan pengaruh masyarakat muslim terhadap pembangunan Masjid/Musholah yang ada di Sulawesi Selatan. Berdasarkan tujuan penelitian, maka metode penelitian

\footnotetext{
${ }^{6}$ http://www.hukumonline.com/klinik/detail/lt57f306314feb9/persyaratan-pendirian-rumah-ibadat
} 
ini menggunakan metode penelitian kuantitatif. Sedangkan alat analisis yang digunakan dalam penelitian ini adalah analisis korelasi dan analisis regresi.

Analisis korelasi adalah salah satu teknik analisis statistik yang umumnya digunakan untuk menganalisis peristiwa-persistiwa yang terjadi dan mencoba untuk menghubungkannya. Secara sederhana dapat diartikan sebagai hubungan. Namun, ketika dikembangkan lebih jauh, korelasi tidak hanya dapat dipahami sebatas pengertian tersebut. Korelasi merupakan salah satu teknik analisis dalam statistik yang dibunakan untuk menacari hubungan antara dua variabel yang bersifat kuantitatif. Analisis korelasi yang digunakan dalam penelitian ini adalah analsis korelasi Pearson Product Moment. Berikut ini adalah asumsi atau persyaratan yang harus dipenuhi dalam menggunakan analisis korelasi Pearson Product Moment:

1. Variabel yang dihubungkan memiliki skala pengukuran data interval/rasio,

2. Variabel yang dihubungkan datanya berpola linier,

3. Variabel yang dihubungkan mempunyai data yang dipilih secara acak atau random,

4. Variabel yang dihubungkan mempunyai pasangan sama dari subjek yang sama pula

5. Variabel yang dihubungkan mempunyai data yang berdistribusi normal.

Besarnya angka korelasi disebut koefisien korelasi yang dinyatakan dalam lambang $r$. Batas kelayakan nilai $r-1 \leq r \leq 1 . r=+1$ disebut hubungan positif sempurna, sebaliknya jika $r=-1$ disebut hubungan negatif sempurna. Berikut interpretasi nilai $r$, jika nilai $r$ terdapat diantara -1 dan $+1 .^{7}$

Tabel 1. Interpretasi Nilai $r$

\begin{tabular}{|c|l|}
\hline$r$ & \multicolumn{1}{|c|}{ Interpretasi } \\
\hline 0 & Tidak berkorelasi \\
$0,00-0,199$ & Sangat lemah \\
$0,20-0,399$ & Lemah \\
$0,40-0,599$ & Cukup \\
$0,60-0,799$ & Kuat \\
$0,80-1,000$ & Sangat Kuat \\
\hline
\end{tabular}

${ }^{7}$ Usman, Husaini. 2015. Pengantar Statistika.hal200-201. Jakarta : Bumi Aksara. 
Analisis Regresi adalah metode statistika yang digunakan untuk membentuk model hubungan dan signifikansi pengaruh antara variabel terikat (dependen; respon; Y) dengan satu atau lebih variabel bebas (independen, prediktor, X).Analisis regresi yang digunakan dalam penelitian ini adalah analisis regresi linier sederhana, karena hanya memiliki satu variabel bebas. Bentuk umum dari persamaan regresi linier.

$$
\hat{Y}=a+b X
$$

Keterangan :

$\hat{\mathrm{Y}}=$ variabel kriterium

$\mathrm{X}=$ variabel prediktor

$\mathrm{a}=$ bilangan konstan

$\mathrm{b}=$ koefisien arah regresi linier.

Bentuk persamaan regresi tersebut sering dibaca sebagai regresi $\mathrm{X}$ atas $\mathrm{Y}$, artinya regresi $\mathrm{X}$ sebagai variabel prediktornya dengan $\mathrm{Y}$ sebagai variabel kriteriumnya. Sebaliknya ada pula persamaan regresi yang dibaca sebagai regresi $\mathrm{Y}$ atas X.Koefisien arah regresi linier dinyatakan dengan huruf $\mathrm{b}$ yang juga menyatakan perubahan rata-rata variabel $\mathrm{Y}$ untuk setiap variabel $\mathrm{X}$ sebesar satu bagian. Maksudnya ialah bila nilai b positif, maka variabel $\mathrm{Y}$ akan mengalami kenaikan atau pertambahan. Sebaliknya bila $b$ negatif, maka variabel $\mathrm{Y}$ akan mengalami penurunan. ${ }^{8}$

Berikut adalah Asumsi analisis regresi linier sederhana :

1. Skala pengukuran data interval/rasio,

2. Data berpola linier,

3. Data berdistribusi normal (uji normalitas),

4. Uji Heteroskedastisitas

5. Outlier

Penelitian ini menggunakan data yang diperoleh dari Badan Pusat Statistik Provinsi Sulawesi Selatan tahun 2015. Variabel yang diambil ialah jumlah

${ }^{8}$ Usman, Husaini dan Purnomo Setiady Akbar. 2008. Pengantar Statistika. Jakarta: Bumi Aksara. 
masyarakat muslim (variabel $\mathrm{x}$ ) dan jumlah masjid/mushallah (variabel y) dengan beberapa lokasi di Provinsi Sulawesi Selatan dengan 11 kabupaten/kota. Berikut adalah struktur datanya :

Tabel 2. Jumlah Muslim dan Masjid/Mushallah di Sulawesi Selatan 2015. ${ }^{9}$

\begin{tabular}{|l|c|c|}
\hline Kabupaten/Kota & $\begin{array}{c}\text { Masyarakat } \\
\text { Muslim }\end{array}$ & Masjid/Mushallah \\
\hline Bantaeng & 193405 & 522 \\
\hline Jeneponto & 372779 & 644 \\
\hline Takalar & 272137 & 562 \\
\hline Wajo & 424117 & 693 \\
\hline Luwu & 337185 & 613 \\
\hline Soppeng & 206681 & 481 \\
\hline Kepulauan & 108245 & 253 \\
Selayar & 172947 & 313 \\
\hline Barru & 46019 & 175 \\
\hline Tana Toraja & 117635 & 169 \\
\hline Pare Pare & 105987 & 238 \\
\hline Palopo & \\
\hline
\end{tabular}

Langkah-langkah analisis data yang dilakukan sebagai berikut :

1. Analisis Korelasi
a. Membuat scatter plot
b. Pengujian normalitas
c. Menginterpretasikan hasil analisis dan menarik kesimpulan.

2. Analisis Regresi Linier Sederhana
a. Membuat scatter plot
b. Pengujian normalitas
c. Heteroskedastisitas (Uji Glejser)
d. Uji F
e. Interpretasi R Square
f. Menginterpretasikan hasil analisis dan menarik kesimpulan

${ }^{9}$ Badan Pusat Statistik Sulawesi Selatan (https/sulsel.bps.go.id) 
Mifdah Hilmiyah, Analisis Hubungan Fungsional...

\section{PEMBAHASAN}

\section{Statistik Deskriptif}

Provinsi Sulawesi Selatan merupakan provinsi dengan jumlah penduduk beragama islam terbesar ke-8, setelah Provinsi Jawa Barat, Jawa Timur, Jawa Tengah, Sumatera Utara, DKI Djakarta, Lampung, dan Sumatera Selatan. Berdasarkan data dari Badan Pusat Statistik (BPS), Jumlah Penduduk beragama di Provinsi Sulawesi Selatan pada tahun 2015 adalah sebanyak 7.200.938jiwa. Provinsi Sulawesi Selatan terdiri dari 24 Kabupaten/Kota. Berdasarkan sebaran 24 Kabupaten/Kota di wilayah Sulawesi Selatan,akan tetapi dalam penelitian ini hanya digunakan 11 Kabupaten/kota dari 24 Kabupaten/Kota. Berdasarkan histogram di bawah, diperoleh bahwa Kabupaten/Kota yang memiliki penduduk muslim tertinggi dari 11 Kabupaten/Kota yang diteliti yaitu sebanyak 424.117 jiwa, kemudian Kabupaten Jeneponto yaitu sebanyak 372.779 jiwa, Kabupaten Luwu dengan 337.185 jiwa, Kabupaten Takalar 272.137 jiwa, Kabupaten Soppeng yaitu sebanyak 206.681, Kabupaten Bantaeng sebanyak 193.405 jiwa, Kabupaten Barru sebanyak 172.947, Kota Parepare sebanyak 117.635 jiwa, Kepulauan Selayar sebanyak 108.245 jiwa, Kota Palopo sebanyak 105.987 jiwa dan Tana Toraja sebanyak 46.019 jiwa.

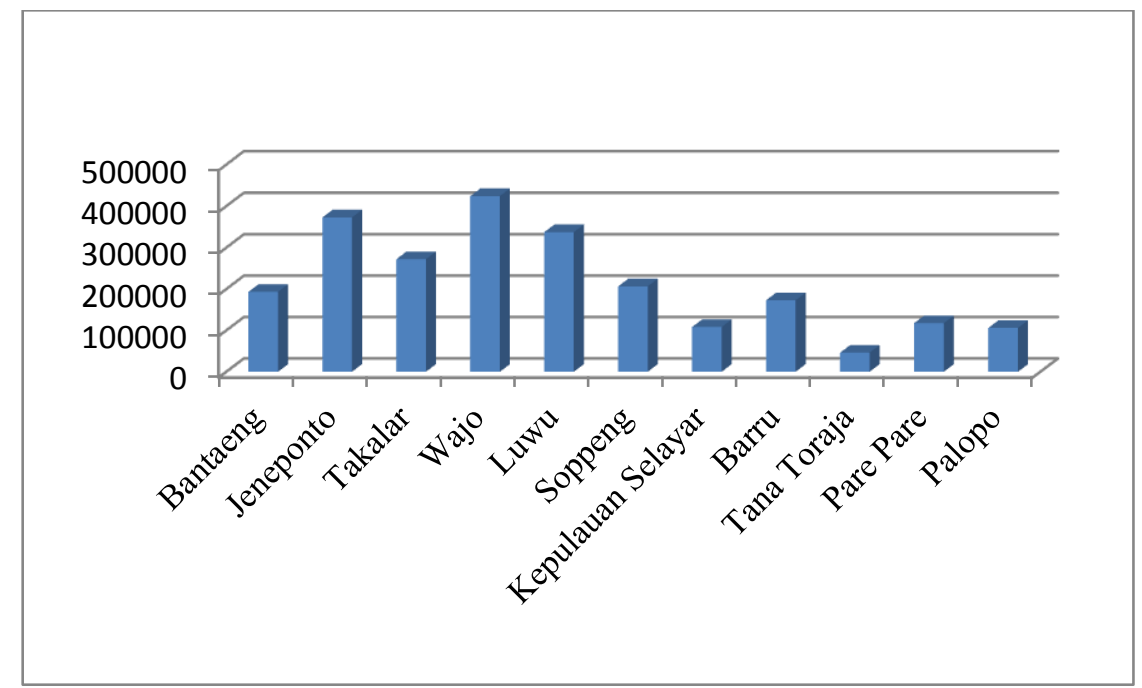

Berikut ini adalah histogram jumlah bangunan masjid/mushallah di Provinsi Sulawesi Selatan berdasarkan Kabupaten/kota tahun 2015. 


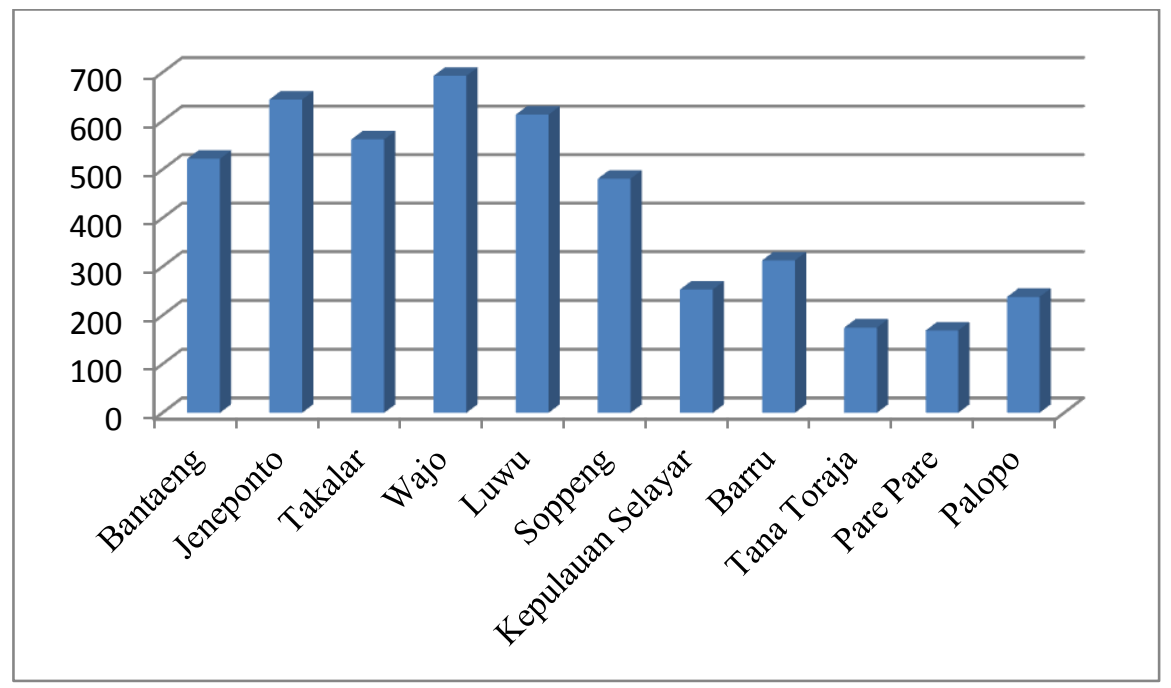

Berdasarkan histogram di atas dapat diketahui bahwa Kabupaten/Kota dengan jumlah masjid/mushallah terbanyak di Provinsi Sulawesi Selatan pada tahun 2015 adalah Kabupaten Wajo yaitu sebanyak 693 masjid/mushallah. Kemudian Kabupaten Jenepontoyaitu sebanyak 644 masjid/mushallah, Kabupaten Luwuyaitu sebanyak 613 masjid/mushallah, Kabupaten Takalaryaitu sebanyak 562 masjid/mushallah, Kabupaten Bantaengyaitu sebanyak 522 masjid/mushallah, Kabupaten Soppeng yaitu sebanyak 481 masjid/mushallah, Kabupaten Barru yaitu sebanyak 313 masjid/mushallah, Kota Palopo sebanyak 238 masjid/mushallah,Kepulauan Selayar sebanyak 253 masjid/mushallah, Tana Toraja sebanyak 175 masjid/mushallah,dan Kota Parepare sebanyak 169 masjid/mushallah.

Sesuai dengan tujuan dari penelitian ini yaitu untuk mengetahui hubungan fungsional jumlah penduduk muslim $(\mathrm{X})$ dan jumlah bangunan masjid/musholah (Y) di Provinsi Sulawesi Selatan, maka dalam melakukan analisis hubungan fungsional antar variabel tersebut, dapat digunakan analisis korelasi untuk mengetahui signifikansi dan besar hubungan antar variabel tersebut dan analisis regresi untuk mengetahui signifikansi pengaruh yang diberikan oleh variabel jumlah penduduk muslim (X) terhadap jumlah bangunan masjid/musholah (Y) di Provinsi Sulawesi Selatan. Sebuah kasus atau data dapat diolah menggunakan analisis korelasi jika memenuhi asumsi analisis korelasi, yaitu data berpola linier dan berdistribusi normal.Begitu halnya dengan analisis regresi, adapun asumsi 
analisis regresi linier sederhana, yaitu data berpola linier, berdistribusi normal, dan tidak terjadi gejala heteroskedastitas.

\section{Uji Asumsi Analisis Korelasi}

\section{Skala Pengukuran Data Interval/Rasio}

Berdasarkan data yang diambil dari Badan Pusat Statistik Sulawesi Selatan dengan variabel penelitian Data jumlah penduduk muslim dan bangunan masjid/mushallah diasumsikan memiliki skala pengukuran datanya rasio.

\section{Data Berpola Linier}

Scatter Plot data jumlah pendudukmuslim(X) dan jumlah masjid/musholah (Y) di Provinsi Sulawesi Selatan.

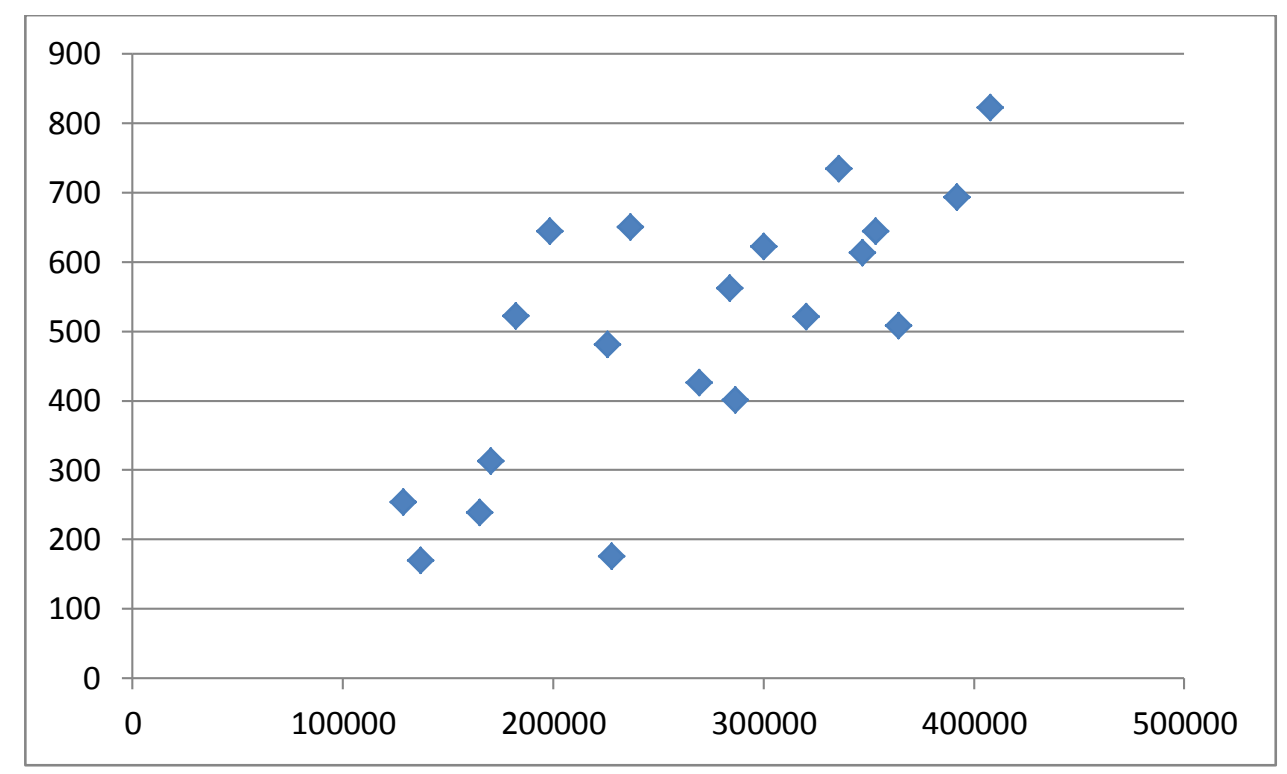

Berdasarkan scatter plot data di atas, menunjukkan bahwa terdapat hubungan fungsional yang linier positif antara jumlah penduduk muslim (X) dan banyaknya bangunan masjid/mushallah (Y) di Provinsi Selatan pada Tahun 2015, artinya semakin tinggi jumlah penduduk muslim di Kabupaten/Kota Provinsi Selatan maka semakin meningkat pula jumlah bangunan mesjid di daerah tersebut.

\section{Uji Asumsi Normalitas}


Mifdah Hilmiyah, Analisis Hubungan Fungsional...

\begin{tabular}{|l|r|r|r|r|r|r|}
\hline & \multicolumn{3}{|c|}{ Kolmogorov-Smirnov(a) } & \multicolumn{3}{c|}{ Shapiro-Wilk } \\
\cline { 2 - 7 } & Statistic & df & \multicolumn{1}{c|}{ Sig. } & \multicolumn{1}{c|}{ Statistic } & df & \multicolumn{1}{c|}{ Sig. } \\
\hline PENDUDUK &, 089 & 20 &, $200\left(^{*}\right)$ &, 959 & 20 &, 533 \\
MASJID &, 125 & 20 &, $200\left(^{*}\right)$ &, 949 & 20 &, 355 \\
\hline
\end{tabular}

* This is a lower bound of the true significance.

a Lilliefors Significance Correction

Berdasarkan output SPSS Test of Normality, diperoleh nilai probabilitas dari metode Kolmogorov - Smirnov dan Shapiro-Wilk lebih besar dari taraf signifikansi penelitian yaitu $\alpha=0,05$, sehingga dapat dinyatakan bahwa data memenuhi uji asumsi normalitas. Seperti yang telah disebutkan di atas, bahwa terdapat dua asumsi analisis korelasi, yaitu data berpola linier dan berdistribusi normal. Sesuai dengan pengujian yang telah dilakukan, kedua asumsi telah terpenuhi, sehingga data tersebut dapat dilanjutkan untuk dianalisis menggunakan analisis korelasi. Berikut ini adalah output SPSS analisis korelasi :

\section{Correlations}

\begin{tabular}{|ll|r|r|}
\hline & & $x$ & \multicolumn{1}{|c|}{$y$} \\
\hline$x$ & Pearson Correlation & 1 &, $945^{\star *}$ \\
& Sig. (2-tailed) & &, 000 \\
& N & 11 & 11 \\
\hline$y \quad$ Pearson Correlation &, $945^{\star *}$ & 1 \\
& Sig. (2-tailed) &, 000 & \\
& N & 11 & 11 \\
\hline
\end{tabular}

${ }^{\star *}$. Correlation is significant at the 0.01 level

\section{Bentuk Hipotesis}

Ho : Tidak terdapat korelasi yang signifikan antara variabel jumlah penduduk muslim dengan variabel jumlah bangunan masjid dan Musholah di Provinsi Sulawesi Selatantahun 2015

$\mathrm{H}_{1} \quad$ : Terdapat korelasi yang signifikan antara variabel jumlah penduduk muslimdengan variabel jumlah bangunan masjid dan Musholah di Provinsi Sulawesi Selatan tahun 2015 
Berdasarkan output SPSS correlations, diperoleh nilai pearson correlation sebesar 0,945, artinya korelasi antara variabel jumlah penduduk dan jumlah bangunan masjid dan musholah di Provinsi Sulawesi Selatan tahun 2015 sangat kuat. Kemudian diperoleh nilai probabilitas 0,000 ,sesuai dengan kriteria pengujian analisis korelasi jika nilai probabilitas $>\alpha=0,05$ jadi, dapat disimpulkan bahwa Ho ditolak atau dengan lain bahwa terdapat korelasi yang signifikan antara variabel jumlah penduduk muslim dan jumlah bangunan masjid dan musholah di Provinsi Sulawesi Selatan tahun 2015.

\section{Uji Heteroskedastisitas}

Coefficients $^{a}$

\begin{tabular}{|c|c|c|c|c|c|c|}
\hline \multirow{2}{*}{\multicolumn{2}{|c|}{ Model }} & \multicolumn{2}{|c|}{$\begin{array}{c}\text { Unstandardized } \\
\text { Coefficients }\end{array}$} & \multirow{2}{*}{$\begin{array}{c}\text { Standardized } \\
\text { Coefficients } \\
\text { Beta }\end{array}$} & \multirow[b]{2}{*}{$t$} & \multirow[b]{2}{*}{ Sig. } \\
\hline & & $\mathrm{B}$ & Std. Error & & & \\
\hline & (Constant) & 51,029 & 27,627 & & 1,847 &, 098 \\
\hline & $x$ & $-1,9 \mathrm{E}-005$ &, 000 &,- 057 &,- 171 & , 868 \\
\hline
\end{tabular}

a. Dependent Variable: RES2

Berdasarkan output SPSS uji heteroskedastisitas, diperoleh nilai probabilitas lebih besar dari taraf signifikansi penelitian yaitu $\alpha=0,05$,sehingga dapat dinyatakan bahwa tidak terjadi gejala heteroskedastisitas. Seperti yang telah disebutkan di atas, bahwa terdapat empat asumsi analisis regresi, yaitu data berpola linier, berdistribusi normal, tidak terjadi gejala heteroskedastisitas dan tidak mengandung outlier. Sesuai dengan pengujian yang telah dilakukan, keempat asumsi telah terpenuhi, sehingga data tersebut dapat dilanjutkan untuk dianalisis menggunakan analisis regresi.

\section{Analisis Regresi Linier Sederhana'}

Coefficients $^{a}$

\begin{tabular}{|ll|r|r|r|r|r|}
\hline \multirow{2}{*}{ Model } & \multicolumn{2}{|c|}{$\begin{array}{c}\text { Unstandardized } \\
\text { Coefficients }\end{array}$} & \multicolumn{2}{c|}{$\begin{array}{c}\text { Standardized } \\
\text { Coefficients }\end{array}$} & \\
\cline { 3 - 4 } & \multicolumn{1}{|c|}{$\mathrm{B}$} & \multicolumn{1}{|c|}{ Std. Error } & \multicolumn{1}{c|}{ Beta } & \multicolumn{1}{c|}{$\mathrm{t}$} & \multicolumn{1}{c|}{ Sig. } \\
\hline 1 & (Constant) & 97,058 & 42,778 & & 2,269 &, 049 \\
& $\mathrm{x}$ &, 002 &, 000 &, 945 & 8,704 &, 000 \\
\hline
\end{tabular}

a. Dependent Variable: $y$ 
Interpretasi Model Regresi

$$
\begin{gathered}
\hat{Y}=a+b X \\
\hat{Y}=97,058+0,002 X
\end{gathered}
$$

Koefisien regresi variabel jumlah penduduk muslim (X) sebesar 0,002, artinya jika variabel jumlah penduduk (X) mengalami kenaikan sebesar 1\%, maka variabel jumlah bangunan masjid dan musholah akan mengalami kenaikan sebesar 0,002. Koefisien regresi bernilai positif artinya terjadi hubungan yang positif antara variabel jumlah penduduk muslim dan jumlah bangunan masjid/musholah di Provinsi Sulawesi Selatan tahun 2015, artinya ketika jumlah penduduk muslim mengalami peningkatanmaka jumlah bangunan masjid/musholah diperkirakan mengalami peningkatan.

\section{Uji Signifikansi}

\section{Bentuk Hipotesis}

Ho : Tidak terdapat pengaruh yang signifikan antara variabel jumlah penduduk muslim

dengan variabel jumlah bangunan masjid/Musholah di Provinsi Sulawesi Selatan tahun 2015

$\mathrm{H}_{1} \quad$ : Terdapat pengaruh yang signifikan antara variabel jumlah penduduk muslim dengan

Variabeljumlah bangunan masjid dan Musholah di Provinsi Sulawesi Selatan tahun

2015

ANOVA $^{\mathrm{b}}$

\begin{tabular}{|ll|r|r|r|r|r|}
\hline \multicolumn{1}{|c|}{} & \multicolumn{1}{|c|}{$\begin{array}{c}\text { Sum of } \\
\text { Model }\end{array}$} & & df & Mean Square & F & Sig. \\
\hline 1 & Regression & 349988,7 & 1 & 349988,703 & 75,766 &, $000^{\circledR}$ \\
& Residual & 41574,206 & 9 & 4619,356 & & \\
& Total & 391562,9 & 10 & & & \\
\hline
\end{tabular}

a. Predictors: (Constant), $x$

b. Dependent Variable: $y$ 
Kriteria pengambilan keputusan pengujian uji $\mathrm{F}$ dapat dilakukan dengan membandingkan $\mathrm{F}$ hitung dengan $\mathrm{F}$ tabel, dengan kriteria pengujian, jika $\mathrm{F}$ hitung $>$ F tabel maka Ho ditolak. Diketahui berdasarkan tabel pengujian di atas diperoleh F hitung sebesar 22,455 dengan F tabel sebesar .... .Karena F hitung > F tabel, maka Ho ditolak artinya terdapat pengaruh yang signifikan antara variabel jumlah penduduk muslim dengan jumlah bangunan masjid/musholah di Provinsi Sulawesi Selatan tahun 2015. Selain itu, juga dapat membandingkan nilai probabilitas dengan taraf signifikansi. Sesuai dengan output SPSS di atas diperoleh nilai probabilitas lebih kecil dari taraf signifikansi yaitu $0,000<0,05$, sehingga dapat dinyatakan bahwa terdapat pengaruh yang signifikan antara variabel jumlah penduduk muslim dengan jumlah bangunan masjid/musholah di Provinsi Sulawesi Selatan tahun 2015.

Model Summary
\begin{tabular}{|l|r|r|r|r|}
\hline Model & \multicolumn{1}{|c|}{ R } & R Square & $\begin{array}{r}\text { Adjusted } \\
\text { R Square }\end{array}$ & $\begin{array}{r}\text { Std. Error of } \\
\text { the Estimate }\end{array}$ \\
\hline 1 &, $945^{\mathrm{a}}$ &, 894 &, 882 & 67,966 \\
\hline
\end{tabular}

a. Predictors: (Constant), $x$

Berdasarkan output SPSS Model Summary diperoleh nilai $\mathrm{R}^{2}$ ( $R$ Square) sebesar 0,894 artinya kontribusi yang diberikan variabel jumlah penduduk muslim (X) terhadap jumlah bangunan masjid/musholah (Y) adalah sebesar 89,4\% selebihnya $10,6 \%$ berasal dari variabel lain.

\section{KESIMPULAN}

Sesuai dengan rumusan masalah penelitian, maka dapat disimpulkan bahwa analisis hubungan fungsional antara jumlah penduduk muslim dan jumlah bangunan masjid/mushallah di Kabupaten/Kota Provinsi Sulawesi Selatan tahun 2015 berpola linier positif, artinya semakin tinggi jumlah penduduk muslimdisuatu daerah, maka semakin banyak pula jumlah bangunan masjid/musholahnya. Berdasarkan hasil pengujian analisis korelasi diperoleh koefisien korelasi antar variabel tersebut tergolong sangat kuat sebesar 0,894 dan signifikan berkorelasi. Sedangkan berdasarkan hasil pengujian analisis regresi, 
diperoleh bahwa terdapat pengaruh yang signifikan antara jumlah penduduk muslim dan jumlah bangunan masjid/musholah di Kabupaten/Kota di Provinsi Sulawesi Selatan.

\section{DAFTAR PUSTAKA}

Muh, Al-hasyimi ali, 2009. Hakikat masyrakat muslim. Indonesia: Islam House

Kurniawan, Syamsul. JurnalVolume 4 no 2 September 2014

Ayub, Moh dkk. Manajemen Masjid 1996. Jakarta. Gema Insani

Farid, Miftah. Lentera Ukhuwah. 2014. Bandung. Penerbit Mizan

Http://www.hukumonline.com/klinik/detail/lt57f306314feb9/persyaratanpendirian-rumah-ibadat

Usman, Husaini dan Purnomo Setiady Akbar. 2008. Pengantar Statistika. Jakarta: Bumi Aksara.

Badan Pusat Statistik Sulawesi Selatan (https/sulsel.bps.go.id) 